\title{
ASSOCIATION BETWEEN QUALITY OF SERVICE AND PATIENT SATISFACTION AT POASIA COMMUNITY HEALTH CENTER IN SOUTHEAST SULAWESI
}

\author{
Nurmaida Saana, Ascobat Gani, Rosarlian
}

Faculty of Public Health, Universitas Indonesia

\begin{abstract}
Background: Patient satisfaction is an indicator of the existing quality of health services. Patient satisfaction can affect patient loyalty of future health service. Recent data showed that outpatient visit to Poasia Community Health Center (Puskesmas) had decreased from 16.74\% in 2012 to $11.38 \%$ in 2013. This study aimed to examine the association between the quality of service and patient satisfaction at Poasia Puskesmas in Southeast Sulawesi.

Subjects and Method: A cross sectional study was conducted in the work area of Poasia Puskesmas, South East Sulawesi, from January to March 2014. A total sample of 97 outpatients was selected for this study at random. The independent variable was outpatient service quality. The dependent variable was patient satisfaction. The quality data were measured by ServQual instrument. Other data were collected using questionnaire and analyzed by chi square test.

Results: The empathy dimension of the quality of health service was positively associated with outpatient satisfaction $(\mathrm{OR}=0.29 ; 95 \% \mathrm{CI}=0.10$ to $0.85 ; \mathrm{p}=0.036)$. Other dimensions of quality were also associated but not statistically significant with patient satisfaction.

Conclusion: Quality of health service is associated with patient satisfaction. The empathy dimension of quality should be capitalized to improve the quality of outpatient service.
\end{abstract}

Keywords: quality, service, patient satisfaction

\section{Correspondence:}

Nurmaida Saana. Faculty of Public Health, Universitas Indonesia, Depok, West Java. Email: nurmaidasaanasaputri@gmail.com. Mobile: 081341815157.

\section{BACKGROUND}

The most important means of basic health services in Indonesia is the Community Health Center (Puskesmas). Community Health Center is one of the many health facilities utilized by the community. Community Health Center is a strategic unit in supporting the realization of changes in public health status towards improving optimal health status (Indonesia health profile, 2013).

Quality of service is an important factor in the utilization of health services. Evaluation of good service quality is not limited to physical healing, but also the attitude, knowledge and skills of officers in providing services, communication, information, courtesy, timely, responsive and the availability of adequate physical environment and facilities. There are five main factors in determining the quality of service, namely: appearance (tangible), reliability, responsiveness, assurance, and empathy. Based on the five dimensions will be known whether the effect of the five dimensions of service quality on patient satisfaction or not. It also can be seen that the most dominant dimensions of service quality affect patients' satisfaction (Pohan, 2015).

Patient satisfaction is a person feeling of pain or disappointment resulting from comparing a product received performance (or outcome) in relations to the person expectation. Patient satisfaction is basically satisfying patients with expectations and understanding patient needs. Community Health Center services are still largely very 
limited, both in terms of personnel, facilities and infrastructure, availability of medicines, facilities, costs and medical services. The level of customer satisfaction with services is an important factor in developing a service delivery system that is responsive to customer needs, minimizing costs and time and maximizing the impact of services on the target population.

Outpatient services at community health centre are one of the first-level individual health efforts. The percentage of outpatient visits at the Poasia Health Center has decreased, in 2010, as many as $21.63 \%$ of the 21,469 population. In 2011 the number of visits was $18.85 \%$ of the 22.507 population. In 2012 , it was $16.74 \%$ of the 23,469 population. In 2013 the number of visits was $11.85 \%$ of the 25474 population (Poasia Health Center Profile, 2013).

The data from the Health Office of Kendari shows that the average number of visits at the Poasia Health Center in 2010 was 45 visits per day, in 2011 it decreased to 47 visits per day, in 2012 it increased to 45 visits per day, and in 2013 decreased to 41 visits per day (Kendari City Health Office Annual Report, 2013).

Poasia Health Center data on reports of the number of community visits to outpatient units from January to March 2014 has decreased. The number of visits in January was 4,090 visits, in February there were 3,266 visits and in March there were 2,907 visits.

An initial survey of service quality conducted on April 1, 2014 for 15 outpatients at Poasia Health Center, obtained some information about service complaints at the Health Center such as: attitudes and actions of health workers, waiting times and inaction in providing services. Based on the data and surveys that have been explained, the authors are interested in researching about "Association between Quality of Service and
Patient Satisfaction at Poasia Community Health Center in 2014".

\section{SUBJECTS AND METHOD}

\section{Design of the Study}

This type of study was analytic with an observational approach that used a cross sectional study design. This study was conducted in the work area of Poasia Health Center in January to March 2014.

\section{Population and Sample}

The population in this study was all outpatients at the Poasia Health Center in January to March 2014. The method of sampling was done by simple random sampling technique. The total sample of the study was 97 respondents.

\section{Inclusion and Exclusion Criteria}

Inclusion criteria in this study, namely: 1) Patients can communicate well. 2) Willing to be interviewed and fill out a questionnaire. Exclusion criteria in this study, namely: 1) Patients refused to participate or continue the study, 2) Patients with severe illness who were unable to answer.

\section{Study Variables}

The independent variable was service quality $\left(\mathrm{X} 1=\right.$ tangible; $\mathrm{X}_{2}=$ reliability, $\mathrm{X}_{3}=$ responsiveness, $\mathrm{X}_{4}=$ assurance, $\mathrm{X}_{5}=$ Empathy). The dependent variable was patient satisfaction (Y). The study instrument used was a questionnaire using a Likert scale with primary data. Data analysis was performed with the chi square test.

\section{RESULTS}

The quality of service at the Poasia Health Center felt by patients was quite good in terms of the five dimensions stated namely; Tangible (physical evidence), Reliability, Responsiveness, Assurance and Empathy. In addition, patient satisfaction had also been felt quite good by patients.

Of the total respondents of 97, the distribution of characteristics was mostly at the 
age of $>35$ years, namely 43 people (44.3\%), who worked as traders (27.8\%), with a high school education level (38.2\%). Respondents were mostly female, namely 58 people (59.8\%) compared to men, 39 people (40.2\%).

In this study, the results showed that the majority of respondents said the quality of tangible (X1) was good, as many as 80 people (82.5\%) and answered poor as many as 17 people (17.5\%). Respondents who stated the quality of reliability (X2) was poor as many as 52 people (53.6\%) and stated good as many as 45 people (46.4\%). On the quality of responsiveness $\left(\mathrm{X}_{3}\right)$ respondents gave a good rating of 53 people (54.6\%) and not good enough as many as 44 people (45.4\%). In the quality assurance (X4) respondents also gave a good assessment of 51 people
(52.6\%) and poor assessment as many as 46 people (47.4\%). On the quality of empathy (X5), the majority of respondents stated poor as many as 73 people ( $75.3 \%$ ) and respondents stated good as many as 24 people (24.7\%).

The majority of respondents stated that the level of satisfaction obtained from the quality of services received was poor as many as 57 people (58.8\%) and 40 people $(41.2 \%)$ satisfied based on the overall quality of service items in the outpatient unit at the Poasia Health Center.

After univariate analysis, it was continued with an analysis to see the association between service quality and patient satisfaction (relationship $\mathrm{X}_{1}, \mathrm{X}_{2}, \mathrm{X}_{3}, \mathrm{X}_{4}, \mathrm{X}_{5}$ with $Y)$. Table 1 showed the results of bivariate analysis.

Table 1. Univariate Analysis of Association between Service Quality and Patient Satisfaction in Outpatients at the Poasia Health Centre in 2014

\begin{tabular}{|c|c|c|c|c|c|c|c|c|c|c|}
\hline \multirow{3}{*}{ No } & \multirow{3}{*}{ Variable } & \multirow{3}{*}{ Category } & \multicolumn{4}{|c|}{ Satisfaction Level } & \multicolumn{2}{|c|}{ Total } & \multirow{3}{*}{$\mathbf{p}$} & \multirow{3}{*}{$\mathbf{O R}$} \\
\hline & & & \multicolumn{2}{|c|}{ Satisfied } & \multicolumn{2}{|c|}{$\begin{array}{c}\text { Dissatisfie } \\
\text { d }\end{array}$} & \multirow[b]{2}{*}{$\mathbf{n}$} & \multirow[b]{2}{*}{$\%$} & & \\
\hline & & & $\mathbf{n}$ & $\%$ & $\mathbf{n}$ & $\%$ & & & & \\
\hline \multirow[b]{2}{*}{1} & \multirow[b]{2}{*}{ Tangible } & Good & 37 & 46.3 & 43 & 53.8 & 80 & 82.47 & \multirow[b]{2}{*}{0.057} & \multirow[b]{2}{*}{ - } \\
\hline & & $\begin{array}{l}\text { Poor } \\
\text { Good }\end{array}$ & 3 & 17.6 & 14 & 82.4 & 17 & 17.53 & & \\
\hline \multirow[b]{2}{*}{2} & \multirow[b]{2}{*}{ Reliability } & Good & 18 & 40 & 27 & 60 & 45 & 46.39 & \multirow[b]{2}{*}{0.981} & \multirow[b]{2}{*}{ - } \\
\hline & & $\begin{array}{l}\text { Poor } \\
\text { Good }\end{array}$ & 22 & 41.2 & 30 & 57.7 & 52 & 53.61 & & \\
\hline \multirow[b]{2}{*}{3} & \multirow[b]{2}{*}{ Responsiveness } & Good & 23 & $43 \cdot 4$ & 30 & 56.6 & 53 & 54.64 & \multirow[b]{2}{*}{0.790} & \multirow[b]{2}{*}{ - } \\
\hline & & $\begin{array}{l}\text { Poor } \\
\text { Good }\end{array}$ & 17 & 38.6 & 27 & 61.4 & 44 & $45 \cdot 36$ & & \\
\hline \multirow[b]{2}{*}{4} & \multirow[b]{2}{*}{ Assurance } & Good & 20 & 39.2 & 31 & 60.8 & 51 & 52.58 & \multirow[b]{2}{*}{0.826} & \multirow[b]{2}{*}{-} \\
\hline & & $\begin{array}{l}\text { Poor } \\
\text { Good }\end{array}$ & 20 & $43 \cdot 5$ & 26 & 56.5 & 46 & $47 \cdot 42$ & & \\
\hline \multirow[b]{2}{*}{5} & \multirow[b]{2}{*}{ Empathy } & Good & 5 & 20.08 & 19 & 79.2 & 24 & 24.74 & \multirow[b]{2}{*}{0.036} & \multirow{2}{*}{$\begin{array}{c}0.29 \\
(0.10- \\
0.85)\end{array}$} \\
\hline & & $\begin{array}{l}\text { Poor } \\
\text { Good }\end{array}$ & 35 & $47 \cdot 9$ & 38 & 52.1 & 73 & 75.26 & & \\
\hline
\end{tabular}

Source: Primary Data

From table 1, the results of the study showed that the largest percentage of respondents who had a good tangible quality dimension perception were 80 respondents
(82.47\%). Chi-square test results obtained $\mathrm{p}=$ 0.057 ( $p>0.05$ ) shows that Ho was accepted, which means there was no association between tangible quality dimensions with the 
level of patient satisfaction. Of the 17 respondents who had a poor tangible quality dimension perception, 3 of them were satisfied and 14 others were dissatisfied.

The results of the analysis of the dimensions of reliability quality with the level of patient satisfaction using the Chi-square test obtained $\mathrm{p}=0.981(\mathrm{p}>0.05)$ shows that Ho was accepted. It means there was no association between the dimensions of reliability quality with the level of patient satisfaction. The percentage of respondents who have a good perception of the quality dimensions of reliability were 45 respondents (46.39\%). Of the 52 respondents who had perceived poor quality dimensions, 22 were satisfied and 30 were dissatisfied.

The results of the analysis of responsiveness quality dimensions with the level of patient satisfaction using the Chi-square test obtained $\mathrm{p}=0.790$ ( $\mathrm{p}>0.05$ ) shows that Ho was accepted. It means that there was no association between the dimensions of responsiveness quality with the level of patient satisfaction. The percentage of respondents who had the good perceived responsiveness quality dimensions were 53 respondents (54.64\%). Of the 44 respondents who had a poor perception of the quality dimension of responsiveness, 17 of them were satisfied and 27 other respondents were dissatisfied.

The results of the analysis of the dimensions of quality assurance with the level of patient satisfaction using the Chisquare test obtained results $(\mathrm{p}=0.826$ $<0.05$ ), indicating that Ho was accepted. It means that there was no association between the dimensions of quality assurance with the level of patient satisfaction. The percentage of respondents who had a good perception of the quality assurance dimension was 51 respondents (52.58\%). Of the 46 respondents who had a poor perception of the quality dimension of reliability, 20 of them were satisfied and 26 of the other respondents expressed dissatisfaction.

The results of the analysis of empathy quality dimensions with the level of patient satisfaction using the Chi-square test obtained results $(p=0.036<0.05)$. Shows that Ho was rejected which means there was an association between the dimensions of empathy quality and the level of patient satisfaction. From the results of the analysis also obtained the value of $\mathrm{OR}=0.29$ means that patients who have a poor perspective on the dimensions of empathy quality have a 0.29 higher odds of experiencing dissatisfaction compared to patients with good perspective.

\section{DISCUSSION}

Moison, Walter, and White cited in Rahayu Sri (2013), mentioned the factors that affect consumer satisfaction, one of which is the decoration of rooms, buildings, and uncomplicated designs. The layout and decoration of the puskesmas also determine the comfort of the puskesmas and the satisfaction of patients or costumers. The tangible aspect of Poasia Health Center in the average patient stated that it was good with $82.5 \%$. However, it is considered important for Poasia Health Center to be able to improve the quality of service in this physical aspect dimension.

Reliability is an important factor in service quality. The willingness and readiness of employees to help customers and deliver services quickly is one of the key dimensions of service quality revealed by Pararusman et al. Therefore, the outpatient part of the Poasia Health Center needs to improve the quality of services, especially in terms of service reliability because this can affect patient perceptions of service quality (Tjiptono, 2016).

Some basic dimensions of service quality according to Parasuraman are responsiveness, including the attitude of courtesy, respect, attention, and friendliness of 
employees who play an important role in improving service quality. Besides communication aspects also include meaning to convey information to customers in a language that is easy for them to understand and always listen to customer suggestions and complaints, including an explanation of the services offered has an important role in improving service quality (Ririn and Mastuti, 2013) . The percentage of respondents who had the perceived responsiveness quality dimensions both in the Outpatient section of the Poasia Health Center were 53 respondents (54.64\%). Based on the results of the analysis shows that patients have a good perceived responsiveness so that it can be concluded that responsiveness is not related to the level of patient satisfaction. This is reinforced by the results of Bamidele's study (2011) showing that there is no significant association between perceived responsiveness and level of patient satisfaction.

Patient responses regarding the assurance dimension can be interpreted to have a good average score of $52.6 \%$, so that it can be interpreted that the quality of service for the assurance sub-variable in the Outpatient section of the Poasia Health Center is considered to be mostly good. Based on the results of the analysis shows that the patient has a good perception of collateral so that it can be concluded that the collateral has no effect on the level of patient satisfaction. This is confirmed by the results of Irfan (2012) study showing that there is no significant association between the perception of collateral and the level of patient satisfaction.

The empathy dimension is a dimension of service quality in the form of giving serious attention from service providers to individual consumers. Based on this study empathy quality dimensions with the level of patient satisfaction using the Chi-square test results obtained are $(\mathrm{p}=0.036<0.05)$. It shows that Ho is rejected which means there is an association between the dimensions of empathy quality with the level of patient satisfaction. Arianto (2013) mentioned that doctors and patients have very different perspectives on the factors they view as the most basic things in doctor-patient communication. As cited by Dianne Berry (2007), it is explained in the results of a simple study by asking doctors and patients to express their views about good doctors. Doctors state that diagnosis ability is the most important quality of a good doctor, while patients say that listening is the most important aspect. Therefore, it is important for health workers in the Poasia Health Center Outpatient Services to further improve the quality of empathy dimensions such as communication patterns between doctors and patients as well as in the diagnosis and other medical measures.

Categories in the service attributes that contribute directly to value development, respectively: (1) Product and service attributes related to function, quality, price and time; (2) Relationships with customers relating to comfort, personal advice, and responsiveness, and (3) image and reputation relating to knowledge (Purnama, 2013). This reinforces that the services provided by an institution will make an assessment or perception of each user that will lead to feeling satisfied or not using the service.

Wyckof stated that service quality is the expected excellence and control over the level of excellence to meet customer desires. If the service received is as expected, the service quality is perceived as good and satisfying. If the service received exceeds customer expectations, the perceived quality of service is good. Conversely, if the service received is lower than expected, the quality of service is considered poor (Tjiptono, 2014).

The conclusions from the results of this study indicate that there is an association between the dimensions of empathy quality 
with the level of outpatient satisfaction at the Poasia Health Center. Those which are not related to the level of patient satisfaction are tangible quality dimensions, reliability, responsiveness, assurance. After conducting a study, the authors found several limitations in this study, namely the limitations of cost and time and respondents' understanding of the language used in the questionnaire. So that it is expected that the writers or authors can then view related issues as important issues. For Poasia Health Centre, it must continue to improve the quality of services in outpatient services and evaluate by taking into account the dimensions of quality in terms of empathy, especially health workers in providing health services to patients and the importance of using existing information media. Also, it is important to conduct periodic patient satisfaction surveys.

\section{REFERENCES}

Aulia N (2014). Analisis hubungan karakteristik pasien dengan kepuasan pelayanan rawat jalan semarang Eye Center (SEC) RS Islam Sultan Agung Semarang. Jurnal Kesehatan Masyarakat, 2(1). Diakses: Agustus 2019

Arianto (2013). Komunikasi kesehatan (komunikasi antara dokter dan pasien): Universitas Tadulako. Diakses: September 2019

Biyanda E, Antono S (2017). Analisis tingkat kepuasan pasien terhadap kualitas pelayanan rawat jalan di Puskesmas Semarang Tahun 2017. Jurnal Kesehatan Masyarakat, 5(4): 33-42. Diakses : Agustus 2019

Dinas Kesehatan kota Kendari (2013). Profil Kesehatan Kota Kendari Tahun 2013: Dinas Kesehatan Kota Kendari.
Dinas Kesehatan kota Kendari. (2013). Profil Puskesmas Poasia tahun 2013: Dinas Kesehatan Kota Kendari.

Kementrian Kesehatan Republik Indonesia (2015). Profil kesehatan Indonesia..

Kotler P, Armstrong G (2016). Principles of marketing $16^{\text {th }}$. Prentice Hall International Inc: New Jersey.

Lovelock H, Lauren KW (2015). Manajemen pemasaran jasa. Jakarta: Indeks.

Muninjaya (2014). Manajemen mutu pelayanan kesehatan. Jakarta : EGC

Nurhayati (2014). Faktor responsiveness terhadap kepuasan pasien di pelayanan Kesehatan Ibu dan Anak (KIA). Jurnal Health Quality, 4(2): 77-141. Diakses: Agustus 2019

Parasuraman A, Zeithml VA, Berry L (2010). Delivering Quality Service: Balancing Customer Perceptions and Expections. The Free Press: New York NY.

Pohan (2015). Jaminan mutu layanan kesehatan dasar-dasar pengertian dan penerapan. Jakarta: EGC

Purnama Nursyabani (2013). Manajemen kualitas perspektif global. Yogyakarta: Ekonisia.

Rahmawati, Supriyanto (2013). Pelayanan kesehatan berdasarkan dimensi dabholkar di ruang rawat inap penyakit dalam. Jurnal Administrasi Kesehatan Indonesia, 1(2). Diakses: Juni 201

Ririn, Mastuti (2013). Manajemen pemasaran jasa. Jakarta: Ghalia Indonesia.

Tjiptono (2016). Pemasaran jasa-prinsip, penerapan dan penelitian. Yogyakarta: ANDI.

Tri Utami (2013). Pengaruh kualitas pelayanan terhadap kepuasan pasien. Jurnal JKMP, 1(1): 83-96. Diakses: September 2019 